\title{
ANGGARAN BERBASIS KINERJA, SUMBER DAYA MANUSIA DAN KUALITAS ANGGARAN SKPD (Suatu Pengujian Struktural)
}

\author{
Devie Octariani ${ }^{1}$ \\ * Pemerintah Daerah Kabupaten Sumbawa \\ *dee.octa.dee@gmail.com ${ }^{1}$ \\ $\mathrm{Akram}^{2}$ \\ * Fakultas Ekonomi dan Bisnis Universitas Mataram (UNRAM), Mataram-NTB \\ *mm_akram2004@yahoo.com ${ }^{2}$ \\ Animah $^{3}$ \\ * Fakultas Ekonomi dan Bisnis Universitas Mataram (UNRAM), Mataram-NTB \\ *animahmtr@yahoo.co.id ${ }^{3}$
}

\begin{abstract}
The aims of this study are to examine and analyze the effect of implementation of performance based budgeting, and quality of human resources to regional work unit's (SKPD) budget qualities. Goal Setting Theory and agency theory are used to explain the phenomenon of budget qualities. The number of respondents in this study were 94 respondents that selected using purposive sampling method, the criteria that SKPD which has been tested for compliance by the Ombudsman in 2015 related to quality of service. This research uses analytical techniques Partial Least Square (smartPLS) 3.0. The results of quantitative analysis in this study showed that implementation of performance based budgeting, and quality of human resources had influence on SKPD's budget qualities. The implications of this study can be useful for SKPDs on local governments to implement the principles of good governance and performance-based budgeting in the budget process to be able to provide better services to the public.
\end{abstract}

Keywords: Budgeting, Budget Qualities, Performance Based Budgeting, Quality of Human Resources.

\section{Pendahuluan}

Kegiatan perencanaan dan penganggaran yang melibatkan seluruh unsur pelaksana yang ada di SKPD mulai dari penentuan program dan kegiatan, klasifikasi belanja, penentuan standar belanja, penentuan indikator kinerja dan target kinerja, sampai dengan jumlah anggaran yang harus disediakan, memerlukan perhatian yang serius bagi pimpinan SKPD beserta pelaksana program dan kegiatan (Sembiring, 2009). Perhatian yang serius ditunjukan dengan menyusun anggaran yang berkualitas yaitu pengalokasian anggaran sesuai dengan kemampuan daerah dan rencana pembangunan daerah yang menunjukkan keinginan Pemerintah Daerah untuk mewujudkan peningkatan kesejahteraan masyarakat melalui pelayanan publik yang terbaik. Menurut Sumiran (2013), "pemerintah daerah tidak akan dapat mengelola keuangannya secara efektif apabila sistem perencanaan dan penganggaran yang dimilikinya buruk".

Sejak diterbitkannya Peraturan Pemerintah (PP) Nomor 58 tahun 2005 tentang Pengelolaan Keuangan Daerah yang diikuti dengan diterbitkannya Peraturan Menteri Dalam Negeri (Permendagri) Nomor 13 Tahun 2006 tentang Pedoman Pengelolaan Keuangan Daerah terakhir diubah dengan Permendagri Nomor 21 Tahun 2011, terjadi perubahan mendasar dalam penyusunan anggaran keuangan daerah, yaitu diperkenalkannya pendekatan penganggaran berbasis kinerja (ABK). Menurut Hill dan Matthew (2005), penyusunan anggaran dengan pendekatan ABK dapat meningkatkan efisiensi dan pelayanan pemerintah serta meningkatkan kepercayaan diri warga terhadap pemerintah. Hal ini didukung temuan penelitian Srithongrung (2009) serta Qi dan Yaw (2012) yaitu ABK efektif untuk mengatur pengeluaran prioritas 
pemerintah. Dalam penerapannya, anggaran disusun dengan menghubungkan hasil kinerja dari alokasi biaya atau input yang ditetapkan, dengan adanya ukuran kinerja, tujuan dan sasaran yang ingin dicapai organisasi menjadi lebih jelas. Oleh karena itu, penyusunan anggaran yang berbasis kinerja diharapkan menghasilkan anggaran yang lebih berkualitas (Robinson, 2006).

Laporan Hasil Kinerja Pemerintah Kabupaten Sumbawa (LkjIP) tahun 2015, menunjukan bahwa ada $40 \%$ indikator kinerja atau sebanyak 139 dari 341 indikator yang diukur dengan realisasi capaian kinerja kurang dari $85 \%$ sementara realisasi keuangan mencapai $88,51 \%$. Masih banyak indikator kinerja dengan capaian kinerja kurang dari $85 \%$ menunjukan anggaran yang disusun oleh Pemerintah kabupaten Sumbawa masih belum menggunakan data yang akurat sehingga terdapat ketidaksinkronan antara capaian anggaran dengan capaian indikator kinerja

Permasalahan lain yang kerap terjadi terkait anggaran yaitu penganggaran belanja yang belum optimal, sehingga berdampak pada penyerapan APBD yang tidak maksimal dan cenderung terjadinya penyerapan pada akhir tahun (Elyas, 2015). Pada tahun 2015, meskipun secara umum kinerja belanja Pemerintah Kabupaten Sumbawa meningkat 15\% dibanding tahun 2014, tetapi masih ada 2 SKPD tingkat penyerapan belanja dibawah $60 \%$ yang berakibat pada program dan kegiatan yang telah direncakan tidak bisa dilaksanakan sepenuhnya. Hasil penelitian Kaharuddin (2012) mengenai analisis faktor-faktor yang mempengaruhi penyerapan belanja daerah di Pemerintah Kabupaten Sumbawa menunjukkan bahwa faktor pelaksanaan anggaran dan faktor penganggaran merupakan 2 faktor utama yang mempengaruhi penyerapan belanja daerah di Kabupaten Sumbawa. Menurut Juliani dan Mahfud (2014), anggaran belanja yang tidak terserap akan menghilangkan manfaat belanja, dan jika manfaat belanja hilang, maka rencana pembangunan dan pelayanan publik kepada masyarakat tidak akan optimal. Penyerapan anggaran yang tidak maksimal dapat terjadi akibat adanya tumpang tindih anggaran serta kesalahan dalam hal penganggaran. Kesalahankesalahan dalam penganggaran dapat terjadi akibat kegagalan menerjemahkan konsep penyusunan anggaran.

Sejalan dengan hal tersebut, Rahayu, et al. (2007) dalam hasil penelitiannya menyatakan bahwa aparatur yang terlibat langsung dalam proses penyusunan anggaran tidak mengerti dan tidak memahami tentang proses penyusunan anggaran saat ini sehingga dalam penyusunannya belum memperhatikan indikator kinerja untuk keluaran dan hasil yang ingin dicapai dari suatu program/kegiatan, akibatnya dapat menurunkan efisiensi dan pelayanan pemerintah serta menurunkan kepercayaan diri warga terhadap pemerintah. Oleh karena itu, aparatur penyusun anggaran harus mampu memahami prosedur dan ketentuan-ketentuan yang bersifat fundamental yang perlu diperhatikan serta kemampuan rasional untuk mengerti secara keseluruhan maksud yang tertuang dalam dokumen-dokumen yang digunakan sebagai pedoman penyusunan anggaran SKPD, seperti Rencana Strategis (Renstra-SKPD), Renja-SKPD, dan Kebijakan Umum Anggaran-Prioritas Plafon Anggaran Sementara (KUA-PPAS). Cipta (2011) menyatakan bahwa kualitas sumber daya manusia merupakan salah satu untur penting dalam kapasitas administrasi publik. Penelitian yang dilakukan oleh Lisnawati dan Dita (2013) membuktikan bahwa sumber daya manusia mempengaruhi kualitas anggaran pemerintah, dan Rasyid (2012) yang menyatakan kapasitas sumber daya manusia mempunyai pengaruh yang dominan terhadap sinkronisasi rencana kerja Pemerintah Daerah (RKPD) dan APBD. Oleh karena itu, sumber daya manusia yang berkualitas diharapkan dapat menghasilkan anggaran yang lebih berkualitas.

Anggaran untuk dapat memiliki kualitas yang baik dibutuhkan proses penyusunan anggaran yang tepat dan sesuai, serta diharapkan pihak-pihak yang terlibat dalam proses penyusunan anggaran dapat secara bijak merumuskan dan menetapkan suatu program dan kegiatan berdasar pada aspirasi masyarakat. Hal ini memotivasi peneliti untuk mengkaji peranan perangkat daerah dalam menjalankan kewenangan untuk menyusun anggaran yang berkualitas, karena anggaran yang disusun adalah anggaran sektor publik yang merupakan instrumen akuntabilitas atas pengelolaan dana publik dan pelaksanaan program-program yang dibiayai dari uang publik (Mardiasmo, 2009:61). Meskipun telah ada ketentuan mengenai penerapan anggaran berbasis kinerja (ABK), kualitas sumber daya manusia merupakan salah satu faktor yang penting dipertimbangkan dalam meningkatkan kualitas anggaran, mengingat sumber daya manusia sebagai 
pilar penyangga sekaligus penggerak roda organisasi dalam usaha untuk mewujudkan visi dan misi serta tujuan organisasi tersebut (Azhar, 2007).

Berdasarkan penjelasan tersebut di atas, maka masalah pokok yang akan dibahas melalui penelitian ini adalah "Apakah penerapan penerapan anggaran berbasis kinerja dan kualitas sumber daya manusia berpengaruh terhadap kualitas anggaran SKPD Pemerintah Kabupaten Sumbawa ?"

Adapun tujuan dari penelitian ini adalah untuk menguji dan menganalisis pengaruh penerapan anggaran berbasis kinerja dan kualitas sumber daya manusia terhadap kualitas anggaran perangkat daerah Pemerintah Kabupaten Sumbawa.

Hasil penelitian ini dapat memberikan pemahaman lebih mendalam mengenai penerapan anggaran berbasis kinerja sehingga anggaran yang dihasilkan mampu meningkatkan kesejahteraan masyarakat melalui pelayanan publik yang terbaik. Penelitian ini penting dilakukan dalam memberikan kontribusi untuk merumuskan kebijakan khususnya yang terkait dengan penyusunan anggaran SKPD. Pendayagunaan anggaran harus sejalan dengan tujuan kinerja yang realistis (dapat dicapai) sehingga menggambarkan hasil yang diharapkan. Pemerintah harus rutin mengevaluasi dan berani memberikan punishment kepada SKPD-SKPD yang memiliki ketimpangan antara capaian kinerja dengan capaian keuangan. Sehingga anggaran yang dialokasikan dapat mencapai tujuan program dan kegiatan dan berimplikasi pelayanan kepada publik yang semakin baik.

\section{Kajian Pustaka dan Pengembangan Hipotesis Goal Setting Theory}

Goal Setting Theory (teori penetapan tujuan) dipelopori oleh Locke (1968), menyatakan bahwa faktor penentu yang penting bagi individu terhadap bagaimana individu tersebut mengerahkan usaha/upayanya adalah terletak pada tujuan individu itu sendiri dan sejauh mana tanggung jawab terhadap tujuan tersebut. Goal Setting Theory mengemukakan tentang: kejelasan, bahwa tujuan harus jelas terukur, tidak ambigu, dan ada jangka waktu tertentu yang ditetapkan untuk penyelesaian tugas; menantang merupakan salah satu karakteristik yang paling penting dari tujuan yaitu tingkat tantangan; komitmen merupakan tujuan harus dipahami agar efektif, bahwa tujuan karyawan konsisten dengan visi dan tujuan perusahaan; umpan balik (feedback) dapat memberikan kesempatan untuk mengklarifikasi harapan, menyesuaikan kesulitan sasaran, dan mendapatkan pengakuan; dan Kompleksitas tugas adalah kehati-hatian manajer untuk memastikan bahwa pekerjaan tidak menjadi terlalu berlebihan agar ada kelonggaran waktu untuk dapat memenuhi tujuan atau meningkatkan kinerja.

Konsep Goal Setting Theory adalah bahwa seseorang yang memahami tujuan akan mempengaruhi perilaku kerjanya, sehingga pemahaman yang baik terhadap tujuan yang tercantum di dalam anggaran akan mempengaruhi kualitas hasil pekerjaannya.

\section{Agency Theory (Teori Keagenan)}

Hubungan keagenan merupakan suatu kontrak dimana satu orang atau lebih (principal) memerintah orang lain (agent) untuk melakukan suatu jasa atas nama principal serta memberi wewenang kepada agent untuk membuat keputusan yang terbaik bagi principal (Jensen dan Meckling, 1976). Hubungan prinsipalagent (keagenan) terjadi ketika tindakan seorang individu mempengaruhi individu yang lain (Smith dan Mark, 1998). Salah satu pihak (principal) membuat suatu kontrak, baik secara implisit maupun eksplisit, dengan pihak lain (agent) dengan harapan bahwa agent akan bertindak/melakukan pekerjaan seperti yang dinginkan oleh principal (dalam hal ini terjadi pendelegasian wewenang). Kesepakatan-kesepakatan dibentuk dalam struktur institusional pada berbagai tingkatan, seperti norma perilaku dan konsep kontrak.

Masalah keagenan muncul ketika hubungan antara principal dan agent dapat mengarah pada kondisi asymmetrical information atau ketidakseimbangan informasi karena agent berada pada posisi yang memiliki informasi yang lebih banyak tentang perusahaan dibandingkan dengan principal. Dengan asumsi bahwa individu-individu bertindak untuk memaksimalkan kepentingan diri sendiri, maka dengan informasi asimetri yang dimilikinya akan mendorong agent untuk menyembunyikan beberapa informasi yang tidak diketahui principal. Jika dilihat dari sudut pandang pemerintahan, masalah keagenan muncul ketika eksekutif cenderung memaksimalkan kepentingan pribadinya yang dimulai dari proses penganggaran, pembuatan keputusan, sampai dengan menyajikan laporan keuangan yang sewajar-wajarnya untuk 
memperlihatkan bahwa kinerja mereka selama ini telah baik, dan juga untuk mengamankan posisi di mata legislatif dan rakyat.

\section{Kualitas Anggaran SKPD}

Anggaran merupakan alat manajemen yang sangat bermanfaat bagi manajemen dalam melaksanakan dan mengendalikan organisasi agar tujuan organisasi tercapai secara efektif dan efisien. Kriteria penganggaran yang baik menurut Egbide dan Godwyns (2012), yaitu (1) anggaran harus membangun posisi fiskal yang stabil dan berkelanjutan untuk jangka menengah dan seterusnya, (2) Anggaran harus memfasilitasi pergeseran sumber daya yang lebih efektif, dengan menggunakan prioritas yang lebih tinggi, (3) Anggaran harus mendorong unit pengeluaran untuk beroperasi secara efisien, (4) Anggaran harus dapat diakses oleh warga dan responsif terhadap kepentingan mereka, (5) anggaran (bersama-sama dengan praktek manajemen keuangan lainnya) harus menjamin akuntabilitas dalam penggunaan dana publik.

Anggaran diperlukan karena ada tujuan dan manfaatnya. Kualitas suatu anggaran dapat tercermin dari manfaat yang dihasilkan dan diberikan dari suatu kegiatan/program kepada masyarakat luas sebagai layanan publik. Menurut Kenis (1979), anggaran tidak hanya sebagai perencanaan keuangan yang menetapkan biaya dan pendapatan pusat pertanggungjawaban dalam suatu organisasi, tetapi juga merupakan alat bagi manajer tingkat atas untuk mengendalikan, mengkoordinasikan, mengevaluasi kinerja, dan memotivasi bawahannya.

Istilah anggaran atau penganggaran (budgeting) sudah tidak asing lagi bagi mereka yang biasa berkecimpung dalam organisasi, termasuk organisasi pemerintahan. Sebagai bagian dari fungsi perencanaan, sebagian besar organisasi modern sudah terbiasa melakukan perencanaan, termasuk perencanaan keuangan (anggaran). Saat ini, organisasi pemerintahan memberikan perhatian yang semakin besar dalam bidang penganggaran. Selain itu, minat publik semakin meningkat pula pada proses pertanggungjawaban dan penyelenggaraan pemerintah daerah semenjak berlangsungnya era otonomi daerah. Dengan kondisi ini pemahaman pada konsep anggaran daerah semakin menjadi kebutuhan.

Anggaran SKPD yang tertuang dalam RKASKPD merupakan dokumen perencanaan dan penganggaran yang berisi rencana pendapatan, rencana belanja program dan kegiatan SKPD serta rencana pembiayaan sebagai dasar dalam penyusunan APBD. Setelah ada nota kesepakatan antara Pemerintah Daerah dan DPRD mengenai kebijakan umum anggaran serta prioritas dan plafon anggaran (KUAPPA), Tim Anggaran (TAPD) menyiapkan surat edaran kepala daerah tentang penyusunan RKASKPD. Dokumen penyusunan anggaran yang disampaikan oleh masing-masing SKPD yang disusun dalam format RKA-SKPD harus betul-betul menyajikan informasi yang jelas tentang tujuan, sasaran, serta korelasi antara besaran anggaran (beban kerja dan harga satuan) dengan manfaat dan hasil yang ingin dicapai atau diperoleh masyarakat dari suatu kegiatan yang dianggarkan.

\section{Penerapan Anggaran Berbasis Kinerja (ABK)}

Anggaran berbasis kinerja (ABK) pada Pemerintah Daerah didasarkan pada terbitnya Keputusan Menteri Dalam Negeri Nomor 29 Tahun 2002 yang berisi panduan membuat anggaran kinerja, pelaksanaan anggaran, sampai dengan pelaporan pelaksanaan anggaran. Regulasi ini disempurnakan dengan diterbitkannya Undang-Undang Nomor 17 tahun 2003 tentang Keuangan Negara yang menjelaskan bahwa rencana kerja dan anggaran disusun berdasarkan prestasi kerja yang akan dicapai atau berbasis kinerja. Disahkannya Peraturan Pemerintah Nomor 58 Tahun 2005 dan dijabarkan lebih lanjut dengan Peraturan Dalam Negeri Nomor 13 Tahun 2006 terakhir diubah dengan Permendagri Nomor 21 Tahun 2011 menguraikan bahwa ABK merupakan upaya untuk memperbaiki proses penganggaran di sektor publik. Penganggaran yang baik akan memberikan dasar pengukuran kinerja dan menghasilkan informasi kinerja yang valid dan akurat, sehingga dapat digunakan sebagai bahan untuk penyusunan laporan kinerja sebagai alat pengendalian.

Robinson dan Brumby (2005) menyatakan "PBB (Performance Based Budgeting) has been defined as procedures intended to "strengthen links between the funds provided to public sector entities and their outcomes and/or outputs through the use of formal performance information in resource allocation decision-making". ABK didefinisikan sebagai prosedur yang dimaksudkan untuk memperkuat hubungan antara dana yang diberikan kepada entitas sektor publik dengan hasil dan/atau output mereka melalui penggunaan informasi kinerja formal dalam mengalokasikan sumber daya dalam mengambil 
keputusan”. Dilakukannya pengukuran kinerja oleh manajer, menurut Behn (2003) dalam Gómez dan Katherine (2008) bertujuan untuk "evaluate, control, motivate, budget, promote, celebrate, learn, and improve". ABK yang didukung oleh sebuah tata kelola pemerintah yang baik (good governace) dan pelaksana yang kompeten, dirasa mampu mereduksi tindakan korupsi, dan meningkatkan kembali rasa kepercayaan dari masyarakat yang telah menghilang. Dalam praktiknya, ABK dipandang dapat meningkatkan proses penganggaran yang sistematis di mana menghubungkan hasil yang diinginkan atas dasar kebijakan negara dengan misi dan tingkat belanja lembaga (Srithongrung, 2009).

Temuan hasil penelitian Hill dan Matthew (2005) dan Gómez dan Katherine (2008) berhasil membuktikan bahwa penerapan pengukuran kinerja dalam penganggaran telah berhasil memajukan komunikasi dan pemahaman di antara pemangku kepentingan tentang apa yang pemerintah lakukan dan bagaimana pelaksanaan program/kegiatan pemerintah dicapai. Hasil ini sejalan dengan temuan penelitian Verasvera (2016) menyimpulkan bahwa ABK memiliki hubungan positif yang kuat dan searah terhadap kinerja aparatur Pemerintah Daerah. Hal ini didukung oleh penelitian yang dilakukan Handayani (2009) dan Maisarah (2014) yang menyatakan bahwa pendekatan kinerja berpengaruh signifikan terhadap kualitas APBD. Berdasarkan teori dan uraian diatas, maka hipotesis yang diajukan sebagai berikut:

H1: Penerapan anggaran berbasis kinerja berpengaruh terhadap kualitas anggaran SKPD.

\section{Kualitas Sumber Daya Manusia}

Kelancaran penyelenggaraan tugas pemerintahan dan pembangunan nasional sangat tergantung pada kesempurnaan aparatur negara. Keterampilan individu seorang aparatur negara mengacu pada tingkat pendidikan dan pelatihan tenaga kerja, dan pengalaman yang diperoleh dalam bidang pengetahuan yang diberikan dari waktu ke waktu. Hal ini diterima secara luas bahwa staf berpendidikan tinggi dan secara teknis yang berkualitas lebih mudah menerima pembauran dan mampu mentransformasi pengetahuan eksternal yang tersedia.

Organisasi pemerintah sebagai agent yang mempunyai tugas memberikan pelayanan kepada masyarakat dalam hubungannya dengan para pemilik anggaran sektor publik sebagai principal, dituntut untuk menggunakan SDM yang berkualitas untuk ditugaskan dalam bagian keuangan, terutama yang akan menangani penganggaran. Peningkatan pengetahuan dan keterampilan pegawai dapat dilakukan dengan memberikan pendidikan dan pelatihan serta menyelenggarakan sosialisasi dan bimbingan teknis tentang peraturan pemerintah terkait anggaran.

Kompleksnya tahapan penganggaran di organisasi sektor publik mulai dari penentuan program dan kegiatan, klasifikasi belanja, penentuan standar belanja, penentuan indikator kinerja dan target kinerja, sampai dengan jumlah anggaran yang harus disediakan, memerlukan SDM yang berkualitas agar tujuan pemerintah untuk peningkatan kesejahteraan masyarakat melalui pelayanan publik yang terbaik yang pengalokasian anggaran sesuai dengan kemampuan daerah dan rencana pembangunan daerah dapat terwujud.

Menurut Ouda (2003) pelaksanaan penganggaran membutuhkan perekrutan staf baru yang berkualitas dan pelatihan untuk staf senior. Hal ini sejalan dengan simpulan penelitian Tayib dan Mohamad (2005) yang menyatakan bahwa permasalahan yang sering terjadi seperti kurangnya tenaga terlatih, kurangnya kemampuan dalam menggunakan data, kurangnya pemahaman menjadi prioritas harus diselesaikan oleh pemerintah terkait penganggaran terutama untuk perencanaan dan pengendalian anggaran. Berdasarkan teori dan uraian diatas, maka hipotesis yang diajukan sebagai berikut:

$\mathrm{H} 2$ : Kualitas sumber daya manusia berpengaruh terhadap kualitas anggaran SKPD

Berdasarkan uraian diatas, maka dapat digambarkan model penelitian berikut ini:

\section{Metode Penelitian}

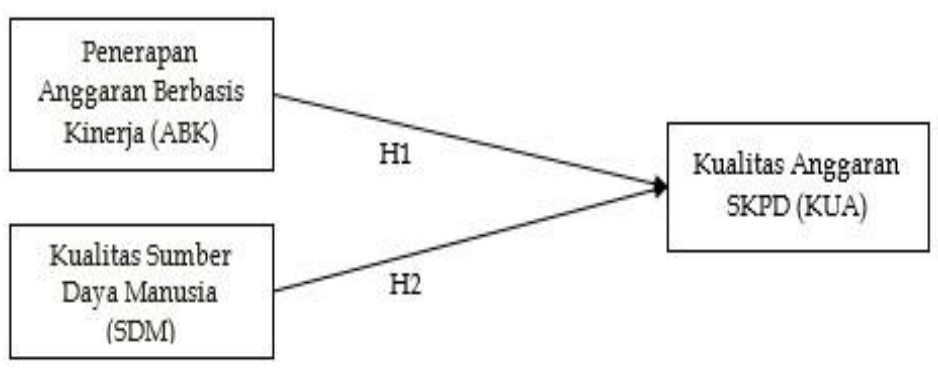

Gambar 1. Model Penelitian 
Penelitian ini adalah penelitian kuantitatif. Berdasarkan tujuannya, penelitian ini merupakan penelitian eksplanatori. dan hubungan yang digunakan pada penelitian ini adalah hubungan kausal, yaitu hubungan yang bersifat sebab akibat.

\section{Populasi dan Sampel Penelitian}

Populasi dalam penelitian ini adalah SKPD yang menyusun anggaran di lingkup Pemerintah Kabupaten Sumbawa yang berjumlah 55 SKPD. Teknik pengambilan sampel dalam penelitian ini adalah non-probability yaitu purposive sampling, dengan kriteria yaitu SKPD yang sudah diuji kepatuhannya oleh Ombudsman pada tahun 2015 terkait kualitas pelayanan, sehingga sampel dalam penelitian ini berjumlah 15 SKPD. Responden pada penelitian ini adalah pegawai yang terlibat dalam penyusunan anggaran dan terkait hasil penilaian Ombudsman sebanyak 100 responden, meliputi: (1) Kepala SKPD, selaku pengguna anggaran, (2) Kepala Seksi/Subbag yang kualitas pelayanannya telah diuji Ombudsman, (3) Kepala Subbagian Program, dan (4) Staf Subbagian Program yang bertugas menginput anggaran SKPD.

\section{Teknik Pengumpulan Data}

Teknik pengumpulan data yang digunakan dalam penelitian ini, adalah kuisioner, masing-masing SKPD didistribusikan kuisioner dan disampaikan langsung oleh peneliti kepada responden penelitian. Sumber data dalam penelitian ini adalah skor masingmasing indikator variabel yang diperoleh dari pengisian kuesioner yang telah dibagikan kepada responden. Dan studi kepustakaan yaitu suatu cara pengumpulan data yang bersumber dari penelaahan kepustakaan, berupa jurnal-jurnal, laporan-laporan, dan referensi lain yang berhubungan dengan permasalahan yang diteliti.

\section{Variabel dan Definisi Operasional \\ Variabel endogen}

Kualitas Anggaran SKPD

Anggaran yang berkualitas adalah pengalokasian anggaran sesuai dengan kemampuan daerah dan rencana pembangunan daerah yang menunjukkan keinginan Pemerintah Daerah untuk mewujudkan peningkatan kesejahteraan masyarakat melalui pelayanan publik yang terbaik (Handayani, 2009). Indikator kualitas anggaran SKPD pada penelitian ini yaitu dukungan unit-unit organisasi (KUA01), keakuratan belanja (KUA02), keakuratan pendapatan (KUA03), relevansi usulan dengan permasalahan terkini (KUA04), tersusun secara smart dan logis (KUA05), tepat waktu (KUA06), memuat informasi biaya (KUA07), memuat informasi kelompok sasaran (KUA08), konsisten dengan dokumen perencanaan (KUA09). Indikator kualitas anggaran dimodifikasi dari penelitian Kenis (1979) dan Puttri (2014).

\section{Variabel eksogen}

Penerapan Anggaran Berbasis Kinerja

Penerapan ABK yang dimaksud dalam penelitian ini adalah upaya yang mengutamakan pencapaian hasil kerja (output/outcome) dari perencanaan alokasi biaya atau input yang telah ditetapkan. Pengukuran variabel ini menggunakan indikator dari penelitian Verasvera (2016) yang dimodifikasi yaitu kejelasan tujuan jangka panjang (ABK01); keselarasan visi, misi, dan tujuan (ABK02); orientasi kepada pendaya-gunaan anggaran (ABK03); input sesuai dengan Rencana Kerja (renja) dan rencana strategis (renstra) (ABK04); output mendukung pencapaian sasaran renja dan renstra (ABK05); berperan dalam melaksanakan tujuan dan sasaran dinas (ABK06); tingkat keberhasilan (ABK07).

Kualitas Sumber Daya Manusia

Kualitas sumber daya manusia adalah kemampuan dari pegawai pada bagian penyusunan anggaran SKPD dalam melaksanakan tugasnya berdasarkan latar belakang pendidikan, pelatihan yang diperoleh, pemahaman mengenai tugas, dan tanggung jawab terhadap kewajiban. Indikator yang digunakan merupakan modifikasi dari penelitian Azhar (2007), yaitu latar belakang pendidikan (LTP), pengalaman (PLM), pembagian tugas (PBT), pengetahuan $(\mathrm{PTH})$, ketepatan waktu (KTW), keahlian (KHL), pelatihan (PLT).

\section{Prosedur Analisis Data}

Pada penelitian ini analisis data menggunakan alat analisis Partial Least Square (PLS) versi 3.0. Penelitian ini menguji tiga variabel eksogen dan satu variabel endogen.

Berikut adalah gambar Model Struktural: 


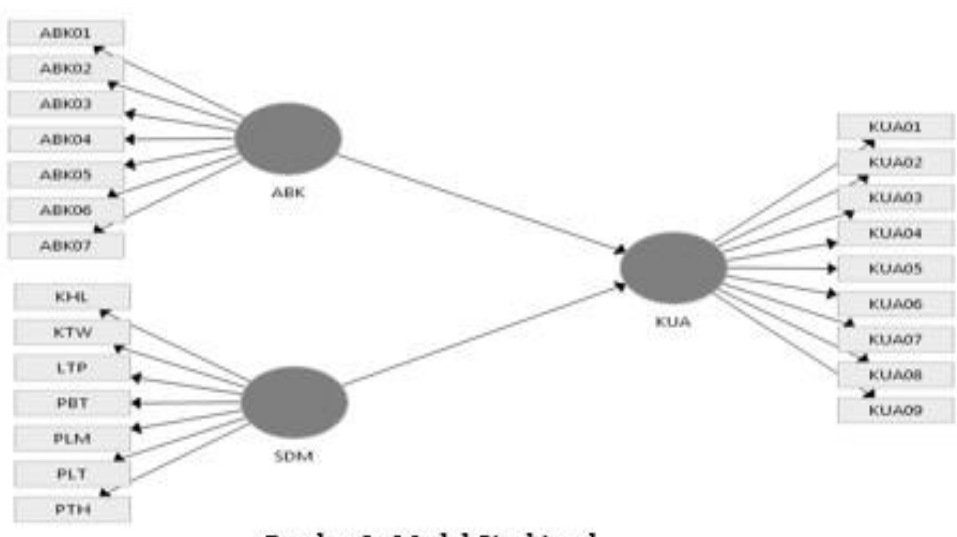

Gambar 2 : Model Struktural

Model persamaan struktural awal diuji dengan persamaan struktural sebagai berikut:

Persamaan Model Pengukuran (Outer Model) variabel KUA

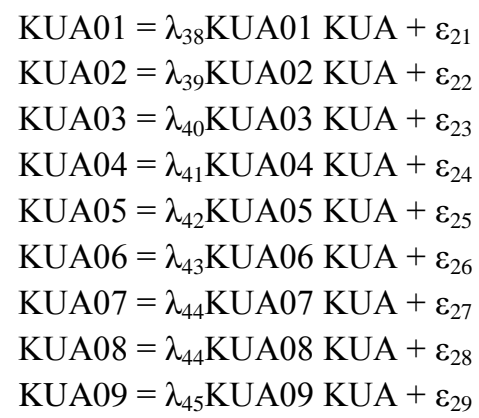

variabel $\mathrm{ABK}$

$\mathrm{ABK} 01=\lambda_{21} \mathrm{ABK} 01 \mathrm{ABK}+\varepsilon_{7}$

$\mathrm{ABK} 02=\lambda_{21} \mathrm{ABK} 02 \mathrm{ABK}+\varepsilon_{8}$

$\mathrm{ABK} 03=\lambda_{22} \mathrm{ABK} 03 \mathrm{ABK}+\varepsilon_{9}$

$\mathrm{ABK} 04=\lambda_{23} \mathrm{ABK} 04 \mathrm{ABK}+\varepsilon_{10}$

$\mathrm{ABK} 05=\lambda_{24} \mathrm{ABK} 05 \mathrm{ABK}+\varepsilon_{11}$

$\mathrm{ABK} 06=\lambda_{25} \mathrm{ABK} 06 \mathrm{ABK}+\varepsilon_{12}$

$\mathrm{ABK} 07=\lambda_{26} \mathrm{ABK} 07 \mathrm{ABK}+\varepsilon_{13}$

Variabel SDM

$\mathrm{LTP}=\lambda_{31} \mathrm{LTP} \mathrm{SDM}+\varepsilon_{14}$

$\mathrm{PLM}=\lambda_{37} \mathrm{PLM}$ SDM $+\varepsilon_{15}$

$\mathrm{PBT}=\lambda_{35} \mathrm{PBT} \mathrm{SDM}+\varepsilon_{16}$

$\mathrm{PTH}=\lambda_{32} \mathrm{PTH} \mathrm{SDM}+\varepsilon_{17}$

$\mathrm{KTW}=\lambda_{36} \mathrm{KTW} \mathrm{SDM}+\varepsilon_{18}$

$\mathrm{KHL}=\lambda_{33} \mathrm{KHL} \mathrm{SDM}+\varepsilon_{19}$

$\mathrm{PLT}=\lambda_{34} \mathrm{PLT} \mathrm{SDM}+\varepsilon_{20}$

Persamaan Model Struktural (Inner model)

$$
\mathrm{KUA}=\gamma_{1} \mathrm{ABK}+\gamma_{2} \mathrm{SDM}+\zeta_{1}
$$

\section{Keterangan :}

$\gamma($ Gamma $)=$ koefisien pengaruh variabel eksogen terhadap variabel endogen

$\zeta($ Zeta $) \quad=$ galat model structural $\lambda($ Lambda $)=$ koefisien model pengukuran

(loading weight)

$\varepsilon($ Epsilon $)=$ galat model pengukuran

KUA = kualitas anggaran SKPD

SDM = kualitas sumber daya manusia

\section{Hasil dan Pembahasan}

Objek penelitian yang digunakan dalam penelitian ini adalah 15 SKPD di Pemerintah Kabupaten Sumbawa yang sudah diuji kepatuhannya oleh Ombudsman pada tahun 2015 terkait kualitas pelayanan. Data yang digunakan yang diperoleh melalui penyebaran kuesioner penelitian kepada pegawai yang terlibat dalam penyusunan anggaran.

Kuesioner penelitian yang disebarkan kepada responden sebanyak 100 kuisioner, dan sebanyak 95 kuisioner telah diterima kembali oleh peneliti sehingga tingkat pengembaliannya (response ratenya) sebesar 95 persen. Dari 95 kuesioner yang diterima kembali tersebut, ada 1 kuisioner yang tidak layak diolah, karena tidak seluruh item pertanyaan pada kusisioner dijawab oleh responden sehingga 1 kuesioner tersebut tidak memenuhi persyaratan untuk diikutkan dalam proses pengolahan data. Rincian kuesioner penelitian dapat dilihat pada Tabel 1.

Tabel 1. Penyebaran dan Pengembalian Kuisioner

\begin{tabular}{lcc}
\hline & Jumlah & Prosentase \\
\hline Jumlah Kuisioner yang disebarkan & 100 & $100 \%$ \\
\hline Jumlah Kuisioner yang tidak dikembalikan & 5 & $5 \%$ \\
\hline Jumlah Kuisioner yang diterima kembali & 95 & $95 \%$ \\
\hline Jumlah Kuesioner yang tidak diisi secara lengkap & 1 & $1 \%$ \\
\hline Jumlah Kuesioner yang bisa diolah lebih lanjut & 94 & $94 \%$ \\
\hline Sumber: data penelitian (2016) & &
\end{tabular}

\section{Karakteristik Responden}

Responden dalam penelitian ini adalah pegawai yang terlibat dalam penyusunan anggaran, meliputi: (1) Kepala SKPD, selaku pengguna anggaran, (2) Kepala Seksi/Subbag yang kualitas pelayanannya telah diuji Ombudsman, (3) Kepala Subbagian Program, selaku pejabat struktural yang mempunyai tugas pokok menyusun dokumen anggaran SKPD, dan (4) Staf Subbagian Program yang bertugas menginput anggaran SKPD lingkup Pemerintah Kabupaten Sumbawa.

Profil responden menunjukkan bahwa jumlah responden perempuan sebanyak 37 responden $(39,36 \%)$ dan responden laki-laki sebanyak 57 
responden $(60,64 \%)$, ini menunjukkan bahwa pegawai yang terlibat dalam penyusunan anggaran berjenis kelamin laki-laki. Data responden juga menunjukan bahwa yang mendominasi adalah responden dengan pendidikan Strata 1 dengan berbagai jurusan/program studi, yaitu sebanyak 68 responden $(72,34 \%)$, data tersebut menunjukkan bahwa responden memiliki tingkat pendidikan cukup memadai. Data pengalaman bekerja menunjukan bahwa 48 responden $(51,07 \%)$ memiliki pengalaman bekerja lebih dari 15 tahun, 35 responden $(37,23 \%)$ memiliki pengalaman bekerja lebih dari 10 hingga 15 tahun, dan jumlah responden dengan pengalaman bekerja lebih dari 5 hingga 10 tahun paling sedikit jumlahnya yaitu 11 responden $(11,70 \%)$. Mengacu pada data tersebut, maka dapat disimpulkan bahwa responden telah memiliki pengalaman kerja yang cukup memadai yang mendukung tugas dan fungsinya dalam melakukan penyusunan anggaran yang berkualitas.

\section{Hasil Statistik Deskriptif}

Data statistik per variabel laten dapat dilihat pada Tabel 3. Tabel tersebut menunjukkan standar deviasi dan nilai rata-rata jawaban responden per variabel laten. Pedoman interpretasi hasil kuisioner untuk menentukan batas bawah dan batas atas setiap kelas terhadap nilai rata-rata masing-masing variabel menggunakan tabel 2 dibawah ini.

Tabel 2. Kategori Penilaian Tanggapan Responden

\begin{tabular}{lccccc}
\hline Kategori & \multicolumn{5}{c}{ Interval } \\
\hline $\begin{array}{l}\text { Kualitas Anggaran } \\
\text { SKPD (KUA) }\end{array}$ & $\begin{array}{c}\text { Sangat tidak } \\
\text { berkualitas }\end{array}$ & $\begin{array}{c}\text { Tidak } \\
\text { berkualitas }\end{array}$ & $\begin{array}{c}\text { Kurang } \\
\text { berkualitas }\end{array}$ & Berkualitas & $\begin{array}{c}\text { Sangat } \\
\text { berkualitas }\end{array}$ \\
\hline $\begin{array}{l}\text { Penerapan Anggaran } \\
\text { Berbasis Kinerja (ABK) }\end{array}$ & $\begin{array}{c}\text { Sangat tidak } \\
\text { diterapkan }\end{array}$ & $\begin{array}{c}\text { Tidak } \\
\text { diterapkan }\end{array}$ & $\begin{array}{c}\text { Kurang } \\
\text { diterapkan }\end{array}$ & \multirow{2}{*}{ Diterapkan } & $\begin{array}{c}\text { Sangat } \\
\text { diterapkan }\end{array}$ \\
\hline Kualitas Sumber Daya & $\begin{array}{c}\text { Sangat tidak } \\
\text { berkualitas }\end{array}$ & $\begin{array}{c}\text { Tidak } \\
\text { berkualitas }\end{array}$ & $\begin{array}{c}\text { Kurang } \\
\text { berkualitas }\end{array}$ & \multirow{2}{*}{ Berkualitas } & $\begin{array}{c}\text { Sangat } \\
\text { berkualitas }\end{array}$ \\
\hline Manusia (SDM) & & & & &
\end{tabular}

Gambaran variabel penelitian yang meliputi: kualitas anggaran (KUA), penerapan anggaran berbasis kinerja (ABK) dan kualitas sumber daya manusia (SDM) dapat disajikan dalam Tabel 3. sebagai berikut :

Tabel 3. Statistik Deskriptif Jawaban Responden

\begin{tabular}{cccccc}
\hline & $N$ & Min & Max & Mean & Std. Deviation \\
\hline KUA & 94 & 1,89 & 5,00 & 4,031 & 0,566 \\
ABK & 94 & 2,57 & 5,00 & 4,102 & 0,524 \\
SDM & 94 & 2,00 & 5,00 & 3,874 & 0,613 \\
\hline Sumber. Output PLS (2016) & & &
\end{tabular}

Riset Akuntansi dan Keuangan Indonesia, 2(1), 2017
Berdasarkan tabel 3 di atas dapat diketahui bahwa variabel KUA memiliki nilai minimum 1,89 dan nilai maksimum 5,00. Nilai standar deviasi sebesar 0,566 lebih kecil dari nilai mean sebesar 4,031. Artinya, nilai sampel dominan berkumpul di sekitar nilai rata-rata hitungnya sebesar 4,031. Hal ini menunjukkan bahwa dilihat dari dukungan unit-unit organisasi, keakuratan belanja, keakuratan pendapatan, relevansi usulan dengan permasalahan terkini, tersusun secara smart dan logis, tepat waktu, memuat informasi biaya, memuat informasi kelompok sasaran, konsisten dengan dokumen perencanaan, maka anggaran SKPD Pemerintah Kabupaten Sumbawa cenderung dalam kategori berkualitas.

Variabel ABK memiliki nilai minimum 2,57 dan nilai maksimum 5. Nilai standar deviasi sebesar 0,524 lebih kecil dari nilai mean sebesar 4,102. Artinya, nilai sampel dominan berkumpul di sekitar nilai rata-rata hitungnya sebesar 4,102. Dari hasil tersebut kemudian disesuaikan dengan tabel kriteria penilaian tanggapan responden. Nilai mean sebesar 4,102 mendiskripsikan kecenderungan responden menjawab untuk pertanyaan-pertanyaan mengenai penerapan ABK adalah anggaran berbasis kinerja dalam penyusunan anggaran SKPD cenderung dalam kondisi atau kategori diterapkan dengan baik.

Variabel Kualitas SDM memiliki nilai minimum 2,00 dan nilai maksimum 5,00. Nilai standar deviasi sebesar 0,613 lebih kecil dari nilai mean sebesar 3,874. Artinya, nilai sampel dominan berkumpul di sekitar nilai rata-rata hitungnya sebesar 3,874 . Hal ini menunjukkan bahwa, SDM penyusun anggaran yang dimiliki SKPD Pemerintah Kabupaten Sumbawa cenderung dalam kategori berkualitas dilihat dari latar belakang pendidikan (LTP), pengalaman (PLM), pembagian tugas (PBT), pengetahuan (PTH), ketepatan waktu (KTW), keahlian (KHL), dan pelatihan (PLT).

\section{Hasil Pengujian Outer Model, Inner model, dan Goodness of Fit}

Metode analisis data yang digunakan adalah Struktural Equation Modelling (SEM) berbasis varian atau biasa disebut dengan soft modeling, dengan menggunakan alat analisis Partial Least Square (PLS). Pada penelitian ini pengujian dilakukan dengan bantuan program SmartPLS 3.0. Dalam PLS atau component based SEM, hubungan linear yang optimal antar variabel laten dihitung dan diinterpretasikan 
sebagai hubungan prediktif terbaik yang tersedia dengan segala keterbatasan yang ada, sehingga kejadian yang ada tidak dapat dikendalikan secara penuh (Ghozali, 2015:6).

Terdapat beberapa alasan yang menjadi penyebab digunakan PLS dalam suatu penelitian. Dalam penelitian ini alasan-alasan tersebut yaitu: pertama, PLS merupakan metode analisis data yang didasarkan asumsi data tidak harus berdistribusi normal multivariate (indikator dengan skala kategori, ordinal, interval, sampai ratio dapat digunakan pada model yang sama), sampel tidak harus besar, yaitu jumlah sampel kurang dari 100 atau minimal 30 bisa dilakukan analisis. Kedua, PLS dapat digunakan untuk mengkonfirmasi teori, yang masih dikatakan lemah, karena PLS dapat digunakan untuk prediksi, tetapi dapat juga digunakan untuk menjelaskan ada atau tidaknya hubungan antar variabel laten. Ketiga, PLS memungkinkan algoritma dengan menggunakan analisis series ordinary least square (OLS) sehingga diperoleh efisiensi perhitungan olgaritma. Keempat, pada pendekatan PLS, diasumsikan bahwa semua ukuran variance dapat digunakan untuk menjelaskan (Ghozali, 20012:4).

Tahapan dan Hasil Pengujian menggunakan alat analisa smartPLS. Ada 2 (dua) permodelan yang digunakan, yaitu: 1. Model measurement/ pengukuran (outer model) merupakan model pengukuran yang menghubungkan indikator dengan variabel latennya, digunakan untuk uji validitas dan reliabilitas, dan 2 . evaluasi measurement/ model struktural (Inner model), merupakan model struktural yang menghubungkan antar variabel laten, digunakan untuk uji kausalitas (pengujian hipotesis dengan model prediksi).

Tiga kriteria model measurement yang digunakan dalam teknik analisa data adalah convergent validity, composite reability dan discriminant validity.

Hasil uji outer untuk melihat nilai convergent validity, didapatkan hasil estimasi perhitungan nilai factor loading untuk semua indikator pada variabel kualtas anggaran (KUA), penerapan anggaran berbasis kinerja (ABK), kualitas sumber daya manusia (SDM). Loading factor yang nilainya dibawah 0,50 akan didrop dari analisis karena memiliki nilai convergent validity rendah. Pada tahap ini, tidak ada indikator yang didrop karena nilai Loading factor pada tiap-tiap indikator lebih dari 0,50. Jadi dapat disimpulkan bahwa, seluruh data dalam diagram full model adalah valid.
Hasil uji dapat dilihat pada gambar 3 dibawah ini.

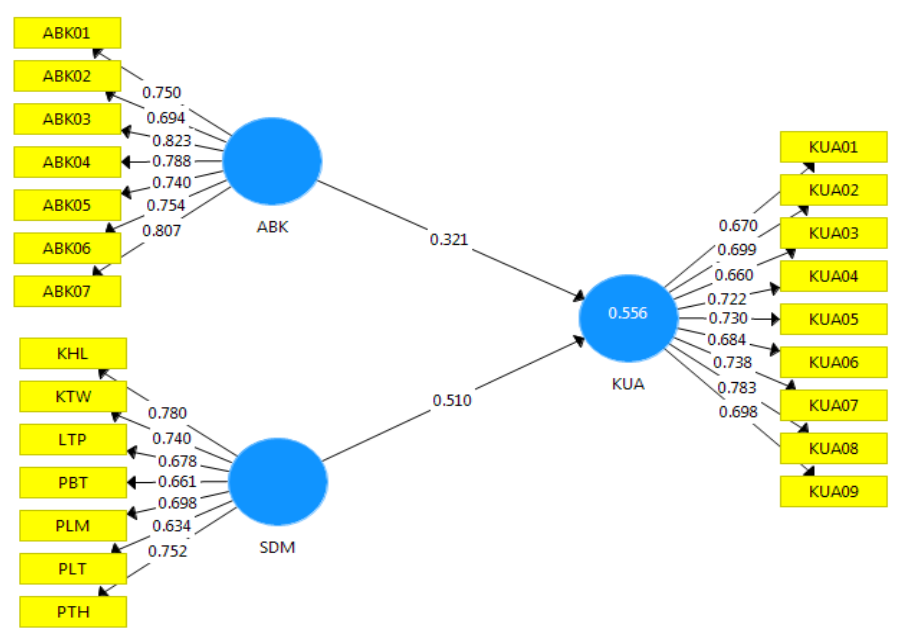

Gambar 3. Hasil Outer Loading PLSAlgorithm

Uji reliabilitas adalah alat untuk mengukur suatu kuesioner yang merupakan indikator dari variabel atau konstuk. Suatu alat ukur atau instrumen yang berupa kuesioner dikatakan dapat memberikan hasil ukur yang stabil atau konstan, bila alat ukur tersebut dapat diandalkan atau reliabel. Suatu konstruk dikatakan reliabel jika nilai composite reliability maupun cronbach alpha di atas 0,70 (Ghozali, 2008:43). Hal tersebut menunjukan konsistensi dan stabilitas instrumen yang digunakan tinggi.

Berikut merupakan data hasil analisis dari pengujian composite reliability maupun cronbach's alpha:

Tabel 4. Hasil Composite Reliability dan Cronbach's Alpha

\begin{tabular}{ccc}
\hline & Composite Reliability & Cronbach's Alpha \\
\hline KUA & 0,901 & 0,877 \\
\hline ABK & 0,908 & 0,883 \\
\hline SDM & 0,875 & 0,834 \\
\hline
\end{tabular}

Sumber: Output PLS (2016)

Hasil pengujian pada Tabel 4 menunjukan bahwa hasil composite reability maupun cronbach's alpha menunjukan nilai yang memuaskan yaitu nilai masing-masing variabel diatas nilai minimum 0,70 . Hal tersebut menunjukan konsistensi dan stabilitas instrumen yang digunakan tinggi. Dengan kata lain semua konstruk atau variabel penelitian ini sudah 
menjadi alat ukur yang fit, dan semua pertanyaan yang digunakan untuk mengukur masing-masing konstruk memiliki reliabilitas yang baik.

Uji discriminant validity menggambarkan korelasi antara variabel dengan nilai korelasi cross loading seluruh indikator yang digunakan dalam membentuk variabel laten, dinyatakan valid apabila nilai korelasi cross loading lebih besar dibandingkan dengan korelasi terhadap variabel laten yang lain.

Nilai cross loading masing-masing variabel dijelaskan pada Tabel 5 berikut ini:

Tabel 5. Hasil Cross Loading

\begin{tabular}{cccc}
\hline & KUA & ABK & SDM \\
\hline KUA01 & $\mathbf{0 , 6 7 0}$ & 0,380 & 0,485 \\
\hline KUA02 & $\mathbf{0 , 6 9 9}$ & 0,218 & 0,425 \\
\hline KUA03 & $\mathbf{0 , 6 6 0}$ & 0,393 & 0,356 \\
\hline KUA04 & $\mathbf{0 , 7 2 2}$ & 0,464 & 0,471 \\
\hline KUA05 & $\mathbf{0 , 7 3 0}$ & 0,490 & 0,469 \\
\hline KUA06 & $\mathbf{0 , 6 8 4}$ & 0,502 & 0,593 \\
\hline KUA07 & $\mathbf{0 , 7 3 8}$ & 0,442 & 0,552 \\
\hline KUA08 & $\mathbf{0 , 7 8 3}$ & 0,507 & 0,557 \\
\hline KUA09 & $\mathbf{0 , 6 9 8}$ & 0,484 & 0,487 \\
\hline ABK01 & 0,278 & $\mathbf{0 , 7 5 0}$ & 0,414 \\
\hline ABK02 & 0,411 & $\mathbf{0 , 6 9 4}$ & 0,410 \\
\hline ABK03 & 0,532 & $\mathbf{0 , 8 2 3}$ & 0,546 \\
\hline ABK04 & 0,514 & $\mathbf{0 , 7 8 8}$ & 0,520 \\
\hline ABK05 & 0,558 & $\mathbf{0 , 7 4 0}$ & 0,375 \\
\hline ABK06 & 0,443 & $\mathbf{0 , 7 5 4}$ & 0,379 \\
\hline ABK07 & 0,485 & $\mathbf{0 , 8 0 7}$ & 0,483 \\
\hline LTP & 0,353 & 0,269 & $\mathbf{0 , 6 7 8}$ \\
\hline PLM & 0,545 & 0,352 & $\mathbf{0 , 6 9 8}$ \\
\hline PBT & 0,417 & 0,301 & $\mathbf{0 , 6 6 1}$ \\
\hline PTH & 0,563 & $\mathbf{0 , 5 3 1}$ & $\mathbf{0 , 7 5 2}$ \\
\hline KTW & 0,551 & 0,507 & $\mathbf{0 , 7 4 0}$ \\
\hline KHL & 0,516 & 0,492 & $\mathbf{0 , 7 8 0}$ \\
\hline PLT & 0,452 & $\mathbf{0 , 3 8 3}$ & $\mathbf{0 , 6 3 4}$ \\
\hline
\end{tabular}

Sumber: Output PLS (2016)

Tabel 6 menunjukkan bahwa nilai korelasi konstruk dengan item pengukuran lebih besar daripada ukuran konstruk lainnya. Hal tersebut menunjukkan bahwa model memiliki nilai discriminant validity yang baik.

Hasil ketiga kriteria tersebut diatas menunjukan bahwa model penelitian telah memenuhi kriteria uji model pengukuran/ measurement model (outer model).

Persamaan outer model pada penelitian ini adalah sebagai berikut :

a. Untuk variabel $\mathrm{ABK}$

$\mathrm{ABK} 01=0,750 \mathrm{ABK}+0,074$

$$
\begin{array}{ll}
\text { ABK02 } & =0,694 \mathrm{ABK}+0,106 \\
\text { ABK03 } & =0,823 \mathrm{ABK}+0,045 \\
\text { ABK04 } & =0,788 \mathrm{ABK}+0,048 \\
\text { ABK05 } & =0.740 \mathrm{ABK}+0,044 \\
\text { ABK06 } & =0.754 \mathrm{ABK}+0,081 \\
\text { ABK07 } & =0,807 \mathrm{ABK}+0,060
\end{array}
$$

b. Untuk variabel SDM

$$
\begin{array}{ll}
\text { LTP } & =0,678 \mathrm{SDM}+0,107 \\
\text { PLM } & =0,698 \mathrm{KUA}+0,091 \\
\text { PBT } & =0,661 \mathrm{SDM}+0,089 \\
\text { PTH } & =0,753 \mathrm{SDM}+0,064 \\
\text { KTW } & =0,739 \mathrm{SDM}+0,064 \\
\text { KHL } & =0,780 \mathrm{SDM}+0,058 \\
\text { PLT } & =0,634 \mathrm{SDM}+0,060
\end{array}
$$

c. Untuk variabel KUA

$$
\begin{array}{ll}
\text { KUA01 } & =0,670 \mathrm{KUA}+0,105 \\
\text { KUA02 } & =0,690 \mathrm{KUA}+0,095 \\
\text { KUA03 } & =0,660 \mathrm{KUA}+0,069 \\
\text { KUA04 } & =0,722 \mathrm{KUA}+0,063 \\
\text { KUA05 } & =0,730 \mathrm{KUA}+0,074 \\
\text { KUA06 } & =0,684 \mathrm{KUA}+0,072 \\
\text { KUA07 } & =0,738 \mathrm{KUA}+0,082 \\
\text { KUA08 } & =0,783 \mathrm{KUA}+0,041 \\
\text { KUA09 } & =0,698 \mathrm{KUA}+0,087
\end{array}
$$

\section{Uji Model Struktural (Inner model)}

Pengujian inner model atau model struktural dilakukan untuk melihat hubungan antar konstruk, nilai signifikansi dan R-square dari model penelitian. Model struktural dievaluasi dengan menggunakan Rsquare untuk konstruk dependen. Nilai R-square ditampilkan pada Tabel 6 berikut ini:

Tabel 6. R Square

\begin{tabular}{cc}
\hline & R Square \\
\hline KUA & 0,556 \\
\hline ABK & \\
\hline SDM & \\
\hline
\end{tabular}

Sumber: Output PLS (2016)

Pada Tabel 4.13 menunjukan bahwa Nilai Rsquare kualitas anggaran (KUA) sebesar 0,556. Nilai R-square sebesar 0,556 memiliki arti bahwa variabel konstruk kualitas anggaran SKPD (KUA) yang dapat di jelaskan oleh variabel konstruk penerapan anggaran berbasis kinerja (ABK) dan kualitas sumber daya manusia (SDM) sebesar 55,60 persen sedangkan 54,40 persen dijelaskan oleh variabel lain di luar yang diteliti. Semakin besar angka R-square menunjukkan 
semakin besar variabel eksogen tersebut dapat menjelaskan variabel endogen sehingga semakin baik persamaan strukturalnya.

\section{Hasil Pengujian Hipotesis dan Pembahasan}

Pengujian hipotesis yang diajukan dilakukan dengan pengujian model struktural (inner model) dengan melihat nilai R-square yang merupakan uji goodness-fit model. Selain itu juga dengan melihat path coefficients yang menunjukkan koefisien parameter dan nilai signifikansi statistik. Signifikansi parameter yang diestimasi dapat memberikan informasi mengenai hubungan antar variabel-variabel penelitian. Batas untuk menolak dan menerima hipotesis yang diajukan di atas adalah 1,96 untuk $\mathrm{p}<0.05$. Hasil uji dapat dilihat pada gambar 4 dibawah ini.

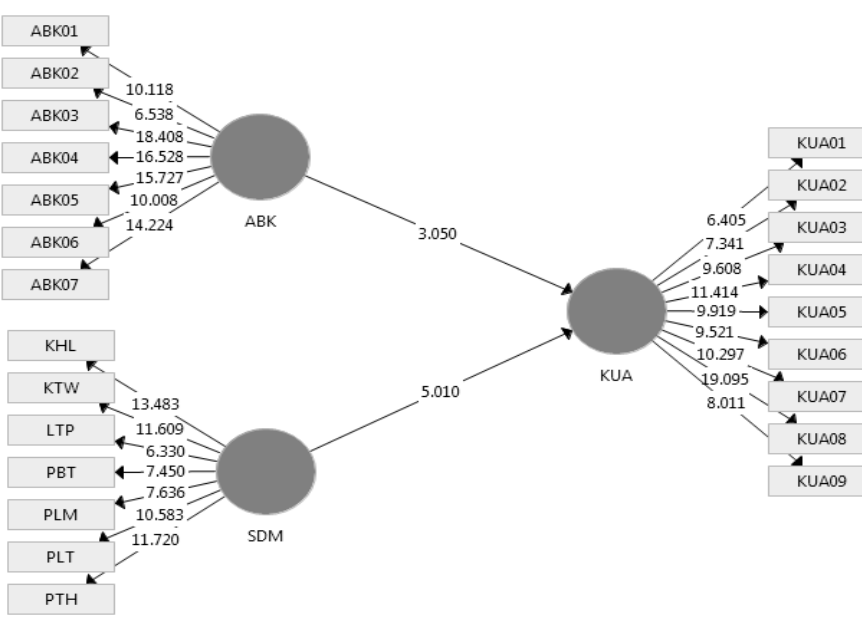

Gambar 4. Hasil Bootstrapping

Persamaan hasil penelitian untuk model struktural (inner model) adalah sebagai berikut:

$\mathrm{KUA}=0,321 \mathrm{ABK}+0,510 \mathrm{SDM}+\zeta$

Keterangan:

KUA = Kualitas Anggaran SKPD

$\mathrm{ABK}=$ Penerapan anggaran berbasis

kinerja

$\mathrm{SDM}=$ Kualitas Sumber Daya Manusia

$\zeta($ Zeta $)=$ galat model struktural

Hasil nilai t-statistik ditunjukkan pada tabel path coefficients sebagaimana disajikan pada Tabel 7 berikut :
Tabel7. Uji Hipotesis berdasarkan Path Coefficient

\begin{tabular}{ccccc}
\hline & Hipotesis & $\begin{array}{c}\text { Loading } \\
\text { Path }\end{array}$ & $\begin{array}{c}\text { T Statistics } \\
(\mid \text { O/STERR } \|)\end{array}$ & Kesimpulan \\
\hline ABK $>\mathrm{KUA}$ & $\mathrm{H}_{2}$ & 0,321 & 3,050 & Hipotesis Diterima \\
\hline SDM $>\mathrm{KUA}$ & $\mathrm{H}$ & 0,510 & 5,010 & Hipotesis Diterima \\
\hline Sumber: Output PLS(2016) & & &
\end{tabular}

Pembahasan

Pengaruh Penerapan Anggaran Berbasis Kinerja terhadap Kualitas Anggaran SKPD

Hasil penelitian $\mathrm{H} 2$ menyatakan bahwa terdapat pengaruh yang signifikan antara penerapan anggaran berbasis kinerja terhadap kualitas anggaran SKPD. Hal ini berarti bahwa penerapan anggaran berbasis kinerja mampu meningkatkan kualitas anggaran SKPD.

Secara umum responden menyadari bahwa pendekatan $\mathrm{ABK}$ penting diterapkan dalam menyusun anggaran yang berkualitas. Hasil penelitian juga menyatakan bahwa dengan menerapkan anggaran berbasis kinerja, anggaran SKPD telah berorientasi kepada pendayagunaan anggaran yang tersedia untuk mencapai hasil yang optimal dari kegiatan yang dilaksanakan, input program dan kegiatan telah diidentifikasikan dengan baik sesuai dengan renja dan renstra, output program dan kegiatan yang direncanakan telah mendukung pencapaian sasaran renja dan renstra, sistem anggaran kinerja telah berperan sebagai patokan dalam melaksanakan tujuan dan sasaran dinas, dan laporan realisasi anggaran SKPD memberikan gambaran yang jelas atas tingkat keberhasilan, serta mendorong aparatur di SKPD untuk selalu meningkatkan kinerja.

Hasil penelitian ini tidak sesuai dengan fenomena-fenomena yang terjadi saat ini dimana laporan hasil kinerja pemerintah kabupaten Sumbawa (LKjIP) yang menunjukan ada $40 \%$ indikator kinerja atau sebanyak 139 dari 341 indikator yang diukur dengan realisasi capaian kinerja kurang dari $85 \%$ sementara realisasi keuangan mencapai $88,51 \%$. Namun, hasil penelitian ini sejalan penelitian yang dilakukan oleh Handayani (2009), Lucyanda (2009), dan Maisarah (2014) yang membuktikan bahwa pendekatan kinerja berpengaruh secara signifikan terhadap kualitas anggaran.

Penelitian lain yang sejalan dikemukakan oleh Klase dan Michael (2008) yang menunjukkan bahwa pelaksanaan anggaran kinerja berpengaruh signifikan 
dan positif pada hasil anggaran diukur dengan pengeluaran per kapita, dan penelitian Qi dan Yaw (2012), bahwa ABK menyebabkan pergeseran dalam pola pengeluaran yang berpotensi pada perbaikan efisiensi dan efektivitas pemerintah.

Temuan ini juga mendukung goal setting theory yang dikemukakan Locke (1968) melalui prinsip kejelasan dan umpan balik, bahwa untuk mencapai tujuan organisasi, ada kejelasan dalam artian jelas terukur dan tidak ambigu atas apa yang akan dihasilkan serta ada jangka waktu yang ditetapkan sehingga membantu manajer untuk melihat apa yang akan dicapai dan memikirkan kembali bagaimana untuk mencapai tujuan menjadi lebih efektif. Sedangkan umpan balik berarti memberikan kesempatan kepada individu untuk dapat menentukan sendiri bagaimana mereka melakukan tugasnya, kesempatan ini diberikan ketika ada interaksi yang ekstensif antara pemilik anggaran, penyusun anggaran, dan pelaksana anggaran dalam proses penentuan tujuan dan pembuatan anggaran yang realistis dan selaras dengan tujuan personal dan kebutuhan para manajer dan bawahan. Kedua prinsip tersebut menjadi poin penting organisasi untuk mencapai tujuan dan sasaran organisasi.

\section{Pengaruh Kualitas Sumber Daya Manusia terhadap Kualitas Anggaran SKPD}

Hasil penelitian $\mathrm{H}_{3}$ menyatakan bahwa terdapat pengaruh antara kualitas SDM terhadap kualitas anggaran SKPD, hal ini berarti bahwa semakin berkualitas SDM, maka anggaran SKPD yang dihasilkan akan semakin berkualitas. Pengaruh signifikan menunjukkan bahwa kualitas sumber daya manusia mempunyai peranan sangat penting dalam meningkatkan kualitas anggaran SKPD. Penelitian ini didukung oleh penelitian yang dilakukan Pratama (2015) bahwa kapasitas sumber daya manusia berpengaruh terhadap ketepatwaktuan penyusunan APBD, Nurhasmah (2015) bahwa kompetensi eksekutif berpengaruh terhadap ketepatan penyusunan APBD, serta penelitian Puttri (2014), Lisnawati dan Dita (2013) yang menyatakan bahwa sumber daya manusia mempengaruhi kualitas anggaran pemerintah.

Pengaruh kualitas sumber daya manusia sangat erat kaitannya dengan teori keagenan yang dikemukakan Jensen dan Meckling (1976). Organisasi pemerintah sebagai agent yang mempunyai tugas memberikan pelayanan kepada masyarakat dalam hubungannya dengan para pemilik anggaran sektor publik sebagai principal, dituntut untuk menggunakan SDM yang berkualitas untuk ditugaskan dalam bagian keuangan, terutama yang akan menangani penganggaran. Masyarakat dewasa ini harus lebih waspada terhadap kurangnya kejujuran dan perilaku yang tidak etis pemerintah dalam hal penyusunan anggaran, ini dikarenakan meskipun masyarakat dimintai pendapatnya melalui forum musrenbang, namun pada akhirnya proses penyusunan anggaran di SKPD tetap dilakukan secara tertutup (Nawawi, 2012).

Kualitas SDM penyusun anggaran di SKPD Pemerintah Kabupaten Sumbawa cenderung dalam kategori berkualitas tetapi belum optimal, salah satu penyebabnya adalah masih ditemukan kesalahan dalam hal penganggaran oleh BPK selama 4 tahun berturut-turut. Berdasarkan hasil penelitian, hal ini dapat disebabkan masih rendahnya SDM yang mengikuti pendidikan dan pelatihan (diklat) penyusunan anggaran, dilihat dari rendahnya nilai mean penilaian tanggapan responden untuk indikator pelatihan dibanding indikator yang lain. Oleh karena itu, Pemerintah Daerah harus memberikan kesempatan kepada SDM penyusun anggaran untuk mengikuti diklat-diklat terkait anggaran agar kemampuan dalam bekerja dapat lebih meningkat sehingga lebih optimal dalam menghasilkan anggaran yang berkualitas.

Pasal 2 ayat 1 Peraturan Pemerintah (PP) No 101 Tahun 2000 tentang Pendidikan dan Pelatihan (Diklat) Jabatan Pegawai Negeri Sipil menjelaskan bahwa salah satu tujuan diklat yaitu untuk meningkatkan pengetahuan, keahlian, keterampilan dan sikap untuk dapat melaksanakan tugas jabatan secara profesional dengan dilandasi kepribadian dan etika PNS sesuai dengan kebutuhan instansi. Selain itu, terbentuknya sikap dan semangat pengabdian yang berorientasi pada pelayanan, pengayoman, dan pemberdayaan masyarakat juga menjadi tujuan diadakannya diklat. Sehingga dengan diberikannya kesempatan diklat kepada SDM penyusun anggaran diharapkan mampu meningkatkan keahlian teoritis, konseptual serta perilaku etis pegawai.

Untuk menyusun anggaran yang berkualitas, selain dibutuhkan pengetahun dan keahlian, individu juga harus memiliki pemahaman mengenai konsep punyusunan anggaran yang baik dan sesuai dengan pedoman yang berlaku. Keikutsertaan dalam diklat terkait anggaran juga menjadi poin penting dalam hal meningkatkan kualitas anggaran. Tanpa adanya hal-hal 
tersebut, maka anggaran yang dihasilkan cenderung tidak akan berkualitas. Rasyid (2012) menyatakan bahwa staf penyusun anggaran harus menjadi fasilitator yang membantu segenap struktur organisasi dalam menyusun komponen-komponen perencanaan yang dimulai dari visi, misi, tujuan, sasaran, program dan kegiatan beserta indikator kinerja yang terukur.

\section{Simpulan}

Penelitian ini bertujuan untuk menguji dan menganalisis pengaruh penerapan anggaran berbasis kinerja dan kualitas sumber daya manusia terhadap kualitas anggaran SKPD Pemerintah Kabupaten Sumbawa. Goal setting theory dan agency theory digunakan untuk menjelaskan fenomena terkait kualitas anggaran. Dengan metode purposive sampling, penelitian ini menggunakan data dari 15 SKPD lingkup Pemerintah Kabupaten Sumbawa. Proses pengolahan data menggunakan alat analisis Partial Least Square (smartPLS) 3.0.

Hasil penelitian menyimpulkan bahwa penerapan anggaran berbasis kinerja berpengaruh terhadap kualitas anggaran SKPD, kualitas sumber daya manusia berpengaruh terhadap kualitas anggaran SKPD.

Temuan lain mengungkapkan bahwa anggaran pendapatan yang tercantum harus lebih objektif dengan perhitungan yang matang, dan perangkat daerah harus mempertimbangkan keikutsertaan penyusun anggaran dalam mengikuti pendidikan dan pelatihan dalam rangka meningkatkan kualitas penyusun anggaran perangkat daerah (SKPD) karena hal tersebut akan berdampak dengan meningkatnya kualitas anggaran SKPD.

Keterbatasan dalam penelitian ini akan memberi arah bagi penelitian mendatang. Pertama, Penelitian ini hanya meneliti tiga variabel yang mempengaruhi kualitas anggaran SKPD, Penelitian ini perlu dikembangkan lebih jauh dengan menambah variabel lain yang diperkirakan dapat mempengaruhi seperti pengawasan anggaran dan penggunaan sistem teknologi informasi dalam penyusunan anggaran. Kedua ruang lingkup pada penelitian ini hanya dilakukan di perangkat daerah yang sudah diuji kepatuhannya oleh Ombudsman pada tahun 2015 terkait kualitas pelayanan sehingga generalisasi hasil temuan dan rekomendasi penelitian ini kurang dapat diberlakukan bagi seluruh perangkat kerja di luar wilayah Kabupaten Sumbawa.

\section{Referensi}

[1] Azhar. 2007. Faktor-Faktor yang Mempengaruhi Keberhasilan Penerapan Permendagri Nomor 13 tahun 2006 pada Pemerintah Kota Banda Aceh. Tesis. Program Pasca Sarjana Universitas Sumatera Utara.

[2] Cipta, Hendra. 2011. Analisis Penerapan Penganggaran Berbasis Kinerja (Performance Based Budgeting) pada Pemerintah Daerah (Studi Eksploratif pada Pemerintah Kabupaten Tanah Datar). Universitas Andalas.

[3] Egbide, C. B dan Godwyns A. Agbude. 2012. Good Budgeting and Good governance: A Comparative Discourse. The Public Administration and Social Policies Review. IV Year, No. 2 (9): 55.

[4] Elyas, Elfin. 2015. Riviu RKA-SKPD. Inspektorat Jendral Kementerian Dalam Negeri.

[5] Ghozali, Imam dan Hengky Lathan. 2012. Partial Least Squares, Konsep Teknik dan Aplikasi, Menggunakan Program SmartPLS 3.0 untuk Penelitian Empiris. Edisi 2. Semarang: Badan Penerbit Universitas Diponogoro.

[6] Gómez, Luis Juan dan Katherine G. Willoughby,.. 2008. Performance Informed Budgeting in U.S. State Governments. Jurnal Presupuesto y Gasto Público 51/2008: 287-303

[7] Handayani, Dwi Bestari. 2009. Pengaruh Reformasi Penyusunan Anggaran terhadap Kualitas APBD Kota Semarang. Jurnal Dinamika Akuntansi, Volume 1 Nomor 1, Maret 2009: 31-40.

[8] Hill, Herb dan Matthew Andrews. 2005. Reforming Budget Ritual and Budget Practice: The Case of Performance Management Implementation in Virginia. Intl Journal of Public Administration, 28: 255-272.

[9] Jensen, M and Meckling, W. 1976. Theory Of The Firm : Managerial Behavior Agency Cost and Ownership Structure. Journal Of Finance Economics 3: 305-360.

[10]Juliani, Dian, dan Mahfud Sholihin. 2014. Pengaruh Faktor-Faktor Kontekstual terhadap Persepsian Penyerapan Anggaran terkait Pengadaan Barang/Jasa. Jurnal Akuntansi dan Keuangan Indonesia, Volume 11 Nomor 2: 177 199.

[11] Kaharuddin. 2012. Analisis Faktor-Faktor yang Mempengaruhi Penyerapan Belanja Daerah di Kabupaten Sumbawa (Studi Kasus : Belanja Dana Alokasi Khusus Bidang Pendidikan, 2010). http://etd.repository.ugm.ac.id. 
[12] Kenis, Izzetin. 1979. "Effects of Budgetary Goal Characteristics on Managerial Attitudes and Performance". The Accounting Review. Vol. LIV, No.4, October: 707-721.

[13] Klase, A Kenneth dan Michael J. Dougherty. 2008. The Impact of Performance Budgeting on State Budget Outcomes. J. of Public Budgeting, Accounting \& Financial Management, 20 (3): 277-298.

[14] Lisnawati dan Dita T. Maliza. 2013. Effect of Human Resources, Ceiling Budget, and the Quality of Regulation Changes in Local Government Provincial Budget Bengkulu. Konferensi Miicema ke-14-IPB. Bogor.

[15]Locke, E. A. 1968. Toward A Theory of Task Motivation and Incentives. American Institutes of Research.

[16] Lucyanda, Jurica dan Maylia P. Sari. 2009. Reformasi Penyusunan Anggaran dan Kualitas APBD. Jurnal Dinamika Akuntansi, Volume 1 Nomor 2, September 2009, pp 76-85.

[17] Maisarah, Santi Fitri. 2014. Pengaruh Akuntabilitas Publik, Partisipasi Masyarakat, Transparansi Publik, dan APBD Berbasis Kinerja terhadap Kualitas Anggaran Pendapatan dan Belanja Daerah (APBD) di Kota Banda Aceh. Universitas Syiah Kuala. Aceh.

[18] Mardiasmo. 2009. Akuntansi Sektor Publik. Penerbit Andi. Yogyakarta.

[19] Nawawi, Juanda. 2012. Membangun Kepercayaan dalam Mewujudkan Good governance. Jurnal Ilmiah Ilmu Pemerintahan. Volume. 1 No. 3.

[20] Nurhasmah. 2015. Pengaruh Peran Dewan Perwakilan Rakyat Daerah (DPRD), Kompetensi Eksekutif dan Komitmen Organisasi terhadap Ketepatan Penyusunan Anggaran Pendapatan dan Belanja Daerah Kabupaten Aceh Utara. Universitas Syiah Kuala. Aceh.

[21] Ombudsman Perwakilan Provinsi NTB. 2016. Ringkasan Hasil Penelitian Kepatuhan Pemerintah Pusat dan Pemerintah Daerah terhadap Standar Pelayanan Publik Sesuai UU No. 25 Tahun 2009 tentang Pelayanan Publik. Mataram.

[22] Ouda, AG. Hassan. 2003. Public Sector Accounting and Budgeting Reform: The Main Issues Involved. Innovation of Public Administration in the Euro-Mediterranean Region (UNDESA). Beirut, E/ESCA/SDPD/2003/WG.5/3.

[23]Pemerintah Kabupaten Sumbawa. 2015. Laporan Kinerja Instansi Pemerintah (LKJIP). Sumbawa.

[24] Pratama, RA. Dian. 2015. Hubungan FaktorFaktor Terhadap Ketepatwaktuan Penyusunan
Anggaran Pendapatan Belanja Daerah Kota Surakarta (Studi Empiris Pada Kantor Pemerintah Kota Surakarta). Naskah Publikasi. Universitas Muhammadiyah. Surakarta.

[25] Puttri, Daniati. 2014. Pengaruh Kompetensi dan Motivasi terhadap Kualitas Anggaran dengan Regulasi sebagai Variabel Moderasi pada Pemerintah Daerah Kota Padang. Universitas Andalas. www.repository.unand.ac.id/20716.

[26] Qi, Yanxia dan Yaw M. Mensah,. 2012. An Empirical Analysis of the Effects of Performance-Based Budgeting on State Government Expenditures. Social Science Research Network. JEL Classification: H72, H75, M49.

[27] Rahayu, Sri, Unti Ludigdo, dan Didied Affandy. 2007. Studi Fenomenologis terhadap Proses Penyusunan Anggaran Daerah Bukti Empiris dari Satuan Kerja Perangkat Daerah di Provinsi Jambi. Jurnal Procedding SNA X. Makassar.

[28]Republik Indonesia. Peraturan Menteri Dalam Negeri Republik Indonesia Nomor 13 Tahun 2006 tentang Pedoman Pengelolaan Keuangan Daerah

[29]_.Peraturan Pemerintah Republik Indonesia Nomor. 58 Tahun 2005 tentang Pengelolaan Keuangan Daerah.

[30] No 101 Tahun 2000 Tentang Pendidikan dan Pelatihan Jabatan Pegawai Negeri Sipil.

[31] Rasyid Abdul. 2012. Analisis Faktor-Faktor Yang Mempengaruhi Sinkronisasi Dokumen Rencana Kerja Pemerintah Daerah Dengan Dokumen Anggaran Pendapatan Dan Belanja Daerah. Laporan Penelitian. Universitas Yapis. download.portalgaruda.org/article.

[32] Robinson, M. And J. Brumby. 2005. Does Performance Based Budgeting Work? An Analytical Review of the Empirical Literature. IMF Working Paper No. WP/05/210. Washington, DC.

[33] Sembiring, Baik Benar. 2009. Faktor-faktor yang Mempengaruhi Penyusunan Anggaran Pendapatan dan Belanja Daerah Berbasis Kinerja (Studi Empiris di Pemerintah Kabupaten (Karo). Tesis. Universitas Sumatera Utara.

[34] Srithongrung, Arwiphawee. 2009. The Effects of Results-Oriented Budgeting on Government Spending Patterns in Thailand. International Public Management Review. Volume 10, Issue 1.

[35] Sugiyono. 2014. Metode Penelitian Kuantitatif, Kualitatif dan $R \& D$. Alfabeta. Bandung.

[36] Sumiran, Bangun Susilo. 2013. Identifikasi Faktor-Faktor Penyebab Terjadinya Keterlambatan dalam Penyusunan APBD (Studi 
Kasus Kabupaten Pesawaran Tahun Anggaran 2012). Universitas Lampung.

[37] Tayib, Mohamad dan Mohamad RA. Hussin,. 2005. Good Budgeting Practice in Malaysian Public Universities. Journal of Finance and Management in Public Services. Volume 3 No. 1.

[38] Verasvera, Febrina Astria. 2016. Pengaruh Anggaran Berbasis Kinerja terhadap Kinerja Aparatur Pemerintah Daerah (Studi Kasus pada Dinas Sosial Provinsi Jawa Barat). Jurnal Manajemen, Volume 15, No.2. 